\title{
INFLUENCE OF BUSINESS PERFORMANCE MEASUREMENT SYSTEMS AND CORPORATE SUSTAINABILITY CONCEPT TO OVERAL BUSINESS PERFORMANCE: "SAVE THE PLANET AND KEEP YOUR PERFORMANCE"
}

\author{
Rastislav Rajnoha, Petra Lesníková, Vladimír Krajčík
}

\section{Introduction}

The examination of the measuring corporate performance issues is dedicated to many authors from different points of view: the relationship of the strategy and strategic orientation to the business performance (Morgan \& Strong, 2003); the view of a strategic measurement performance system through strategic agenda and decision-making as a result of the process of (re)formulating strategy (Bisbe \& Malagueño, 2012); the effect of strategic measurement performance system on the important attributes of the strategy formulating process (Gimbert et al., 2010); the effect of strategic performance measurement system of human resources and corporate results (Bento \& White, 2014); the use of the process performance measurement (Tuček et al., 2013); the relations among customer satisfaction, customer loyalty and financial performance of a commercial bank (Belás \& Gabčová, 2016); the methodology for prediction and detection of the ways of solving demanding situations in managerial work, with obvious implications in performance of managers and in efficiency of business performance management (Lajčin, Frankovský, \& Štefko, 2012); the model of acquisition activity in financial sector (Korauš et al., 2015); performance management and public corporate governance with regard to relationships with both external (stakeholders) and internal (politicians and management) actors (Romolini et al., 2015). Many other empirical studies realized around the world in recent years have also confirmed the relationship between strategic planning and business performance (Rudd et al., 2008).
If we are talking about the need and ability of the system to adapt and operate in the long term period with the orientation of economic, environmental and social performance of enterprise, we refer to a corporate sustainability performance measurement system (Searcy, 2012). According to Maletic et al. (2015) it seems that it exists some support for existence of a business case for corporate sustainability. Using Tobin's q was founded that corporate sustainability is strongly associated with market value (Lo \& Sheu, 2007, p. 355); the greater engagement in sustainability activities can lead to a greater innovation, which in turn leads to greater financial and market performance (Maletic et al., 2015). On the other hand, the analysis of link between corporate social responsibility (in our view a narrower concept as corporate sustainability) and the performance indicators showed that the link between these variables is negative. These results cover this effect only during the first years in which sustainability actions are applied. It will be necessary to examine a longer time period (López et al., 2007). All of these authors state that in the research it is still necessary to provide a clearer understanding. The aim of this paper is to identify the relationship between selected management tools and concepts of various development phases of strategic performance measurement systems to overall business performance measured by indicator ROE. Similarly the aim is to identify the relationship between the sustainability index and indicator ROE as a key aspect in terms of the current extremely advancing climate crisis. 


\section{A Brief Overview of the Performance Measurement Systems}

As the report of RSA Tomorrow's Company shows (Neely et al., 2000), the achievement of sustainable corporate success in the demanding world market depends on the relevant enterprises indicators for the measurement of business performance. Currently, strategic performance management and measuring system can significantly contribute to achieving and solving this gap. From our point of view and after extensive literature resources search, we state that the issue of business performance measurement system was passed the following phases: measurement systems based on purely financial indicators, non-financial performance measurement indicators (impact of technological innovations, environment, etc.), $\mathrm{KPI}, \mathrm{BSC}$, Business Intelligence knowledge information support and finally the sustainability performance measurement system.

\subsection{Financial Business Performance Measurement System}

In the past, the majority of corporate practice methods were concentrated to measure corporate performance refers to mainly the financial performance. Within these measurement systems is based on traditional accounting system (Ahmed et al., 1999). The early performance measures were appropriate to evaluate divisional and managerial performance or the use of standard costing and variance analysis to control production activities (Chenhall \& Langfield-Smith, 2007, p. 266). Cost management is one of the most important issue of company performance and company financial management (Novák \& Popesko, 2014).

Traditional business performance measures have mostly financial character which measures the rate of return on investment, cash flow and profit margins (Gunasekaran $\&$ Kobu, 2007). These measures have been criticized due to their reduced ability of using for comprehensive performance measurement. Value based management system came up with an innovation in the form of indicator EVA (Sharma \& Kumar, 2010).

From $80 \mathrm{~s}$ the traditional accounting measures have been criticized in terms of heavily oriented nature toward internal comparisons of costs and revenues, also a little attention to the external environment; of misleading signals for continuous improvement and innovation, worked well for industrial era (Kaplan \& Norton, 2005); of historical and backward character (Ittner \& Larcker, 1998); furthermore they are focused the outcome instead of being process oriented (Yeniyrt, 2003). Shortcomings of traditional measurement systems triggered a revolution in the business performance measurement (Kennerley \& Neely, 2002). The revolution is a radical decision and changes from the processing of financial measures as a basis for measuring performance for their processing as one of a wider set of measurements. The inadequacy of traditional measurement systems pointed also Research Institute of Management Accountants (1996), when only $15 \%$ of respondents considered their measurement system as supporting the objectives, while $43 \%$ of respondents considered it to be inadequate (Burgess et al., 2007). This showed that enterprises can replace existing traditional measurement systems to those that reflect their current objectives and business surroundings (Kennerley \& Neely, 2002). The results from the data of manufacturing enterprises show that enterprises with more extensive performance measures mainly objective and subjective nonfinancial measures have higher performance (Van der Stede et al., 2006).

\subsection{Strategic Business Performance Measurement System}

Performance measurement system define Gimbert, Bisbe and Mendoza (2010) as a set of financial and non-financial measures to support enterprise decision-making by collecting, processing and analyzing quantified information regarding its performance and presented in a briefreview. Asubsetis aStrategicPerformance Measurement System (SPMS), whose typical feature is the design of these systems to support decision making by managers through financial and also non-financial indicators covering different perspectives and which in combination enables to transform strategy into a comprehensive set of performance measures (Chenhall, 2005). SPMS contributes to the achievement of strategic goals through three mechanisms: a better understanding of the links between different policy priorities, effective communication between the objectives and activities and the efficient allocation of resources and tasks (Dossi \& Pateli, 2010). 
The most typical example of such systems is a BSC. BSC methodology has become popular since their introduction by Kaplan and Norton in 1992. The system itself has undergone development in terms of the change from a traditional point of view to measure performance towards a process where the business is able to measure what it wants, while involving and intangible assets (Perkins et al., 2014). Non-financial indicators are considered as the drivers the future financial performance of the company (Tangen, 2004). This is indicated by the results of research the global consulting firm Bain \& Company in 2015, where the tool BSC was one of the six most widely used management tools among enterprises all over the world (Rigby \& Bilodeau, 2015). This fact confirms the assumption that enterprises consider this tool to be a necessary and effective in strategy implementing and measuring business performance. On the other hand, it is important to misunderstand the BSC as a miraculous tool which somehow improve business performance (Perkins et al., 2014).

In Slovakia or Czech Republic have been also addressed several research of this issue in the recent past, there may be mentioned e.g. research of the SPSM and BSC methodology application in business practice. Gavurová presents the results of the first exhaustive survey in Slovak enterprises implementing BSC (Gavurová, 2011). Other similar research based on a questionnaire survey obtained from the 91 companies from Czech Republic. The study indicates that there is a positive significant relationship between management tools and techniques utilization and organizational performance (Afonina, 2015). The next survey realized in Czech Republic was focusing on the evaluation the impact of the use of BSC in order to achieve greater financial performance of businesses, depending on the size and business sector on a sample of micro, small, medium and large enterprises. This survey showed that out of a total sample of 350 enterprises, only $13 \%$ of them use BSC concept. For companies using the BSC were considered only those businesses that actively use this tool at least two years. The effect of the BSC use and its impact on financial performance was tested using financial indicators ROA and ROE. The research results also did not confirm that the BSC use contributes to improved financial performance of the company. In the research was used a sample of 167 enterprises (Knápková et al., 2014). Important will be also its implementation, as evidenced by the results of such research in Slovakia, implementation of the BSC system only through the software solutions can lead to a false understanding of the meaning of BSC by managers, which is also a common reason for failure to implementation of this system (Šoltés \& Gavurová, 2015). Similar results have also brought other foreign research, which states, that the BSC are associated with higher measurement system satisfaction, but exhibit almost no association with economic performance (Ittner et al., 2003). Another important foreign research, however, says that if the BSC is used primarily for strategic management, then it will also bring higher financial performance (Braam \& Nijssen, 2004).

\subsection{Business Intelligence as a Key Knowledge Information Support for Business Performance Measurement System}

The business impact of SPMS is affected by information technology variables (Internet usage, ERPs, informational technology tools) (Bento et al., 2014). Especially ERP II - BI (Business Intelligence) represents the system that provides the ability to analyze business information in order to support and improve management decision making (Elbashir et al., 2008). Together with the facilitating the decisions communication is in this way supported the corporate performance management (Melchert et al., 2004). For BI success are necessary the technological capabilities such as data quality, user access and the right and whole integration of BI with other existing systems (Işik et al., 2013).

Several studies are devoted to the influence of information technology on business performance. According to the Bento et al. (2014) is evident that information technology variables contribute significantly to the business impact of SPMS. Except of above mentioned benefits, the using of $\mathrm{BI}$ improves the overall enterprise performance (Ranjan, 2009). If the performance measurement systems are supported by appropriate IT platforms it will improve identification of strengths and weaknesses of enterprise, continuous improvement etc. (Nudurupati \& Bititci, 2005) which ultimately can lead to the improvement 
of business performance. Petrini and Pozzebon (2009) suggest that $\mathrm{BI}$ system takes an important role in improving of implementation and monitor sustainable practices. The lack of information support decreases the reliability of information and also inhibits their integration with another indicator for complex decision making. Higher-quality, lower-cost information is a key to unlocking more sources of finance for SMEs (Belás et al., 2016).

The survey carried out on the sample of 164 enterprises operating in Slovakia investigated the implementation, respectively using of $\mathrm{BI}$ in relation to company ROE value. The results show that only $7 \%$ of enterprises have implemented and use a system of $\mathrm{BI}$, whereby these companies belong to the group with the ROE more than $4 \%$. On this basis is displayed the hypothesis that the use of the $\mathrm{BI}$ system will affect the higher business performance. Even $71 \%$ of enterprises not consider an implementing this system into the practice. The research results showed that in the case that companies do not have the $\mathrm{Bl}$ information system as a complex system and not take into account its implementation they tend to have a lower level of performance. On the other hand, businesses that currently use $\mathrm{BI}$ system they achieve a better performance with a ROE of more than $4 \%$. It follows that the $\mathrm{BI}$ system has a major impact on business performance (Rajnoha et al., 2016).

\subsection{Sustainable Performance Measurement System}

A comprehensive view of the business is not possible without neglecting the social and environmental aspects, while highlighting only the economic aspect would not reflect the diversity of processes occurring in the enterprise in relation to the various entities that are perform in the business (Marková, 2012). For these reasons has discovered a new tool for measuring performance - Triple Bottom Line (TBL). The responsibility of a business is not just about generating economic profit (profit), but also about caring for society as a whole (people) and the environment (planet). These three elements are the basis of TBL (Fauzi et al., 2010). This framework for measuring performance created by J. Elkington went beyond the traditional measure of profit and return on owner value with regards to environmental and social dimensions.
The corporate sustainable concept is based on the globally-oriented concept of sustainable development. In general, the most acceptable definitions are those that come from the report of the World Commission of the United Nations Environment and Development. The environmental indicators being assessed can be organized into 3 major groups of environmental indicators: environmental quality, environmentally responsible behaviour, and consumption of environmental services (Streimikiene, 2014). The measurement of sustainability is required due to several reasons (Jurigová \& Lencsésová, 2015). Corporate sustainability strategy is essential for sustainable development, but also for the successful management of the company through the related social, legal, political and economic requirements in terms of market competition (Schaltegger et al., 2012). The social, legal and political environment, which are created by state, play an important role (Virglerová et al., 2016).

In the sustainability issue are used the sustainably oriented key performance indicators. This indicators measure progress toward sustainability and demonstrate the environmental, social and economic impacts. According to Keeble et al. (2003) difficulties in performance measuring accrue mainly from the enterprise complex organizational structure with different trade flows, functions and projects. In order to be able to measure corporate sustainability was developed several methods and models. Global Reporting Initiative created reporting guidelines which provide a framework for the content of the information included in the corporate social responsibility report (Searcy, 2012). The aim of composite index of sustainable development created by Glavic and Krajnc is to provide a simplified and quantified view of the integrated information on sustainable development in case of a more comprehensive number of indicators. Index can be used to inform and support decision-making about development trends and referring to the potential opportunities for improvement in the sustainability areas (Glavic \& Krajnc, 2005).

As we have already mentioned the relationship between corporate sustainability and business performance has carried on many research debates. Some researches declare a positive relationship between corporate sustainability/corporate social responsibility 


\begin{tabular}{|c|c|}
\hline $\begin{array}{l}\text { Overvie } \\
\text { perform }\end{array}$ & $\begin{array}{l}\text { Overview of relationship between corporate sustainability and business } \\
\text { performance }\end{array}$ \\
\hline Author & Description \\
\hline $\begin{array}{l}\text { Eccless, Perkins } \\
\text { and Serafeim }\end{array}$ & $\begin{array}{l}\text { "High sustainability" enterprises outperformed their counterparts in term of stock } \\
\text { market performance and accounting criteria (ROA, ROE). The environmental, } \\
\text { social and governance performance can contribute to financial performance. }\end{array}$ \\
\hline Lo and Sheu & $\begin{array}{l}\text { Using Tobin's q was founded that corporate sustainability is strongly associated } \\
\text { with market value. }\end{array}$ \\
\hline $\begin{array}{l}\text { Servaes } \\
\text { and Tamayo }\end{array}$ & $\begin{array}{l}\text { CSR has a positive impact on financial performance in relation to high } \\
\text { advertising intensity. }\end{array}$ \\
\hline Cochran and Wood & $\begin{array}{l}\text { Within industry groups the financial variable most strongly correlated with CSR } \\
\text { is asset age. After controlling for asset age, using a large sample, and industry- } \\
\text { specific control groups, there still is weak support for a link between CSR and } \\
\text { financial performance. }\end{array}$ \\
\hline Pava and Krausz & $\begin{array}{l}\text { Enterprises which have been met criteria of CSR/sustainability have generally } \\
\text { been shown to have financial performance at least on a par, if not better, than } \\
\text { other enterprises. }\end{array}$ \\
\hline $\begin{array}{l}\text { Koh, Qian } \\
\text { and Wang }\end{array}$ & $\begin{array}{l}\text { It exists the positive relationship between sustainability performance and } \\
\text { financial performance. This relationship is moderated by a firm's financial } \\
\text { distress risk. }\end{array}$ \\
\hline $\begin{array}{l}\text { Waddock and } \\
\text { Graves }\end{array}$ & $\begin{array}{l}\text { Better corporate social performance seems to be positively related to better } \\
\text { financial performance. It can be interpreted in both directions (better financial } \\
\text { performance may lead to improved sustainability performance and vice versa, } \\
\text { ceteris paribus). }\end{array}$ \\
\hline Maletic et al. & $\begin{array}{l}\text { Greater engagement in sustainability activities can lead to a greater innovation, } \\
\text { which in turn leads to greater financial and market performance. }\end{array}$ \\
\hline $\begin{array}{l}\text { Ayvazyan and } \\
\text { Afanasyev }\end{array}$ & $\begin{array}{l}\text { The role of the state and regional governments in the development of innovation } \\
\text { space to support sustainable innovative performance is emphasized. }\end{array}$ \\
\hline López et al. & $\begin{array}{l}\text { The analysis of link between CSR (in our view a narrower concept as corporate } \\
\text { sustainability) and the performance indicators showed that the link between } \\
\text { these variables is negative. It will be necessary to examine a longer time period. }\end{array}$ \\
\hline Garcia Castro et al. & $\begin{array}{l}\text { The positive relationship between social performance and financial performance } \\
\text { which was found in most of the previous research becomes a non-significant or } \\
\text { even a negative while the endogeneity is taken into account. }\end{array}$ \\
\hline Hawn and loannou & $\begin{array}{l}\text { Symbolic actions of environmental, social and governance have a higher impact } \\
\text { on market value in the presence of higher intangible assets, and that a larger } \\
\text { gap between symbolic and substantive actions has a higher positive effect on } \\
\text { firm performance. Substantive actions have a lower or no significant impact on } \\
\text { market value (even though they have a significant positive effect on ROA in the } \\
\text { presence of higher intangibles). }\end{array}$ \\
\hline $\begin{array}{l}\text { Baron, Harjoto } \\
\text { and Jo }\end{array}$ & $\begin{array}{l}\text { For the full dataset CFP and CSP are found to be largely unrelated, which is } \\
\text { consistent with the theories in which CSP provides product differentiation or } \\
\text { the social market line is horizontal. This, however, is an equilibrium relationship } \\
\text { and does not imply the absence of a causal relation between CSP and CFP } \\
\text { for individual firms. The absence of an empirical relation between financial } \\
\text { performance and social performance or the presence of a positive relation for } \\
\text { consumer industries and a negative relation for industrial industries does not } \\
\text { mean that there is no causal relation for an individual firm. }\end{array}$ \\
\hline
\end{tabular}

Source: Eccless et al. (2012); Servaes and Tamayo (2013); Cochran and Wood (1984); Pava and Krausz (1996); Koh et al. (2014); Waddock and Graves (1997); Lo and Sheu (2007); Maletic et al. (2015); Ayvazyan and Afanasyev (2016); López et al. (2007); Garcia Castro et al. (2010); Hawn and loannou (2012); Baron, Harjoto and Jo (2012) 
(CSR), some argue that there is no correlation. In Table 1 we presented some findings in field of business performance.

Based on results of our research we inclined to authors, who state that it exist a positive correlation between corporate sustainability and financial performance. Strategic management tool BSC can also refer to the corporate sustainability concept. In this sense the 'sustainable BSC' extends the traditional perspectives with perspective on the environment and society. Earlier studies identified the existence of the relationship between the characteristics of entrepreneurs and business performance, but the results were still inconclusive (Kozubíková et al., 2015). This may cover the central requirement of the corporate sustainability concept in continuous improvement of business performance in economic, environmental and social terms (Figge et al., 2002). Based on this, it is evident link between performance measurement systems in reaction business sector to the present trends and opportunities.

Due to the aim of paper and from our analytical view defined phases of performance measurement systems, we focused on identifying the impact of the selected tools used in the individual phases to overall business performance measured by indicator ROE. This aim we have transformed into the research hypotheses.

\section{Objectives, Data Collection and Methodology \\ 2.1 Objectives and Research Hypothesis}

The aim of this paper is to identify the relationship between selected management tools and concepts of various development phases of strategic performance measurement systems to overall business performance measured by indicator ROE. Similarly the aim is to identify the relationship between the sustainability index and indicator ROE as a key aspect in terms of the current climate crisis.

To identify the relationship between selected management tools and overall corporate performance, we formatted the following research hypothesis:

H1: We assume that businesses applying the BSC methodology will achieve significantly higher performance.
H2: We assume that if businesses use a system of key performance indicators (KPI) will achieve higher level of performance.

H3: We assume that businesses applying in addition to financial indicators and also non-financial indicator in the form of more orientation on the environment will achieve better performance.

H4: We assume that a stronger emphasis on non-financial, strategic indicators and environment has no significantly negative impact on the financial performance of the company, and they create a Sustainable Performance Measurement System.

\subsection{Data Collection}

The first stage of primary research presented querying selected sample of Slovak enterprises in the form of an online questionnaire focused on the use of selected parameters of performance measurement system. The emphasis was on the investigation of impact these parameters on the overall business performance measured by ROE. In the second phase of research, we focused on exploring issues of measuring corporate sustainability through a sustainable development composite index in a particular manufacturing enterprise and its impact on performance. The conclusion contained assessment of achievements and identification of mutual relationship and strategic performance measurement system and measuring corporate sustainability. Data about the primary database of 1,457 enterprises from selected industries of the Slovak Republic (the greatest extent was enterprises represented by engineering, wood and automotive industries) we received from information of various industrial associations and those we have subsequently supplemented by other companies on the basis of extensive online survey. The questionnaire was distributed in two consecutive rounds. First via e-mail (time for completion was two months, low latency - there were completed only 45 research questionnaires), subsequently we are therefore used in the second round the form of telephone and the most common form of face-to-face interview (time for completion was next two months, there were filled other 119 research questionnaires). After these two consecutive rounds the questionnaires were correctly completed by 164 enterprises in the end. We consider the size of the research sample as being sufficiently representative 
and this is $11.26 \%$ share of the total number of companies surveyed. For this, we could identify and analyze parameters for measuring and managing corporate performance, a key finding was the size of ROE. Based on this, we have incorporated the companies to the performance categories (6 intervals of scale), which are influenced by the lower frequency reduced to 3 respectively 2 performance enterprise categories. We realized that more appropriate indicator would be the indicator EVA, but for its determination it is necessary to know the costs of the own capital, which is in our conditions rather unrealistic. Therefore, we have used more accessible indicator ROE. In view of the sensitivity of the data we have scale a value of $0 \%$ to over $10 \%$. Moreover we considered $6 \%$ of ROE as the moderate value reached in surveyed enterprises. Specification of enterprises is shown in Fig. 1.

\section{Fig. 1: The segmentation of enterprises surveyed into the performance groups}

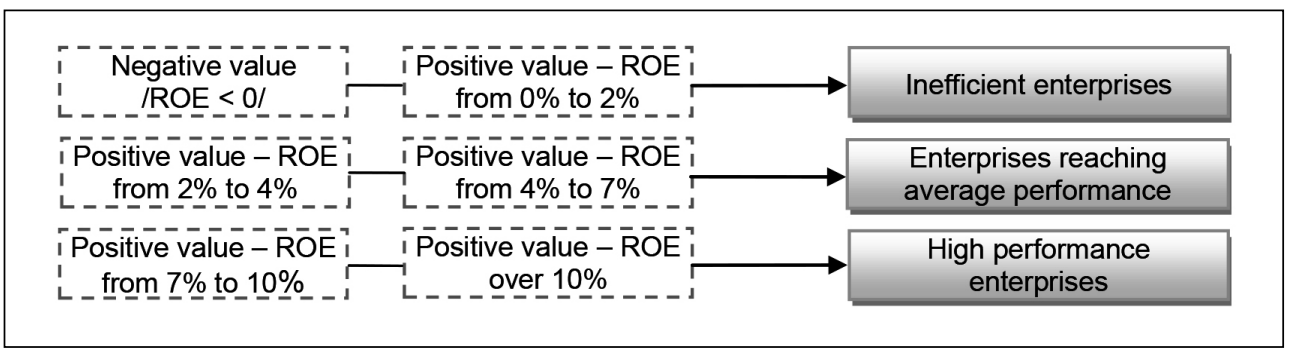

\subsection{Methodology}

In the quantitative part of the research, we did not focus only on traditional financial tools; greater emphasis was therefore put to the BSC and KPI. In the area of non-financial indicators, we focused on companies and their orientation to the environment. The results obtained by questionnaire survey were processed by statistical methods, whereby we except of selected variables of descriptive statistics for one variable (frequency, relative proportions) used mainly Chi-square test of independence. It is used to test the categorical variable weather there is a relationship between these variables or not. In the analyzing this relationship we started from Pivot Tables and Pivot coefficients. The analysis of the difference between observed (empirical) and expected (theoretical) frequency we used Pearson chi-square test. Besides this, we have also used a similar $\mathrm{M}-\mathrm{V}$ chi-square test, which is based on the theory of maximum likelihood and is used in case there is a real between variables dependent. The hypothesis was verified at the $5 \%$ significance level $(\alpha=0.05)$.

In the qualitative part of the research we have created in the condition of particular enterprise a composite index of sustainability which we constructed based on the work of Krajnc and Glavič (2005). For the analysis of industrial enterprise in the automotive industry, we aimed to extract the necessary data from relevant areas and to complete them by sub-indices into a single composite index. In the analysis, we can point out that the company is primarily focused on achieving economic performance, and belongs to the middle of the pollutant, which means that the environmental focus lies primarily on the issue of waste. In terms of social areas it is an enterprise that provides to its employees many advantages. The data we have obtained for a given enterprise, we compared the time period of six years (2009-2014). The following Table 2 contains indicators for the area in the specified units for the period, and its distribution corresponds classified based on the GRI guidelines.

In the economic field we included the traditional indicators $\left(x_{1 i}\right)$ used in accounting as well as intangible assets. Direct impact on the performance of the enterprise is mainly the quality of production, which is expressed through error rate (PPM - Parts per million) and the cost of the claims. Indicators of socio-social 
Tab. 2: Indicators from different areas of corporate sustainability

\begin{tabular}{l|l|l}
\multicolumn{1}{c|}{ Economic indicators } & \multicolumn{1}{c|}{ Social indicators } & \multicolumn{1}{c}{ Environmental indicators } \\
\hline Sales $(€)$ & Donations $(€)$ & Electricity consumption $(\mathrm{MWh})$ \\
\hline Profit $(€)$ & Training costs $(€)$ & Natural gas consumption $\left(\mathrm{m}^{3}\right)$ \\
\hline Capital expenditure $(€)$ & $\begin{array}{l}13^{\text {th }} \text { and } 14^{\text {th }} \text { salary }(\% \text { from gross } \\
\text { wage })\end{array}$ & $\begin{array}{l}\text { Consumption of LPG, propane } \\
\text { butane }(\mathrm{t})\end{array}$ \\
\hline R\&D costs $(€)$ & Zero absence $(\%)$ & Fuel consumption $(\mathrm{t})$ \\
\hline Other fines and penalties $(€)$ & $\begin{array}{l}\text { No. of workers accidents } \\
\text { (number) }\end{array}$ & Water consumption $\left(\mathrm{m}^{3}\right)$ \\
\hline $\begin{array}{l}\text { Average value of PPM } \\
\text { (number) }\end{array}$ & $\begin{array}{l}\text { The number of days due to work } \\
\text { accidents }\end{array}$ & Waste (t) \\
\hline The cost of claims $(€)$ & Gender inequality $(\%)$ & Investments in the environment $(€)$ \\
\hline & & Fines and penalties $(€)$ \\
\hline
\end{tabular}

Source: own

area $\left(x_{2 i}\right)$ reflect the attitude of enterprises to internal groups (employees) and external groups (public). Environmental indicators $\left(x_{3 i}\right)$ involve mainly the areas of consequences on the environment within the individual types of materials in the production. These include a balanced view of the environmental consequences of the inputs and outputs of the company. Subsequently, we assigned to these indicators a character; the positive impact on the sustainable development of enterprise $\left(x_{j i}^{+}\right)$ and the negative impact $\left(x_{j i}^{-}\right)$. Because of the indicators were expressed in different units of measurement, the normalization of their value was needed. One method that can be used is the calculation of standard indicators using the relationships (1) and (2). Normalization of indicators of positive impact is carried out according to equation (1) and normalization of indicators of negative effects is carried out according to equation (2):

$$
\begin{aligned}
& x_{j i t}^{N}=\frac{x_{j i t}^{+}-x_{j i \min }^{+}}{x_{j i \max }^{+}-x_{j i \min }^{+}} \\
& x_{j i t}^{N}=1-\frac{x_{j i t}^{-}-x_{j i \min }^{-}}{x_{j i \max }^{-}-x_{j i \min }^{-}}
\end{aligned}
$$

For the purposes of assessment the importance of individual indicators in the groups in relation to the sustainable development of enterprise, it is necessary establish the weights of relevant indicators $\left(w_{i j}\right)$. In our work, we apply AHP (Analytical Hierarchy Process) method to determine weights. Detailed description of this methodology is stated by Saaty (2008). After these procedures we proceed to the construction the sub-indices of sustainability $\left(I_{s, j}\right)$ of each group of indicators. These subindices are calculated as a weighted average of the individual standardized indicators at the time of the relevant set of indicators as follows:

$$
I_{\mathrm{S}, j t}=\frac{\sum_{i=1}^{n_{j}} w_{j i} \cdot x_{j i t}^{N}}{\sum_{i=1}^{n_{j}} w_{j i}}
$$

Finally, the individual sub-indices of sustainability are aggregated into a single composite index of sustainable development at the time as the weighted average of the individual sub-indices of sustainability as follows:

$$
I_{\mathrm{CSD} t}=\frac{\sum_{j=1}^{3} u_{j} I_{\mathrm{S}, j t}}{\sum_{j=1}^{3} u_{j}}
$$

Composite index has helped us to develop an overall picture of the areas of corporate sustainability with the unveiling of visible reserves and potential opportunities 
for improvement. Finally, we investigated the impact rate of index on performance indicator ROE through Spearmen's coefficient.

\section{Research Results}

\subsection{Non-Traditional Measures and their Impact on Business Performance}

Within the frame of using tools, respectively concepts conducive to improving the performance, we focused on the less frequently used tools in the form of BSC methodology. We were interested in a sub-analysis, whether this concept has a major impact on the overall performance of enterprises. The following Tables 3 and 4 indicated achievements through selected statistical tests.

From the Tables 3, 4 we can see that the BSC methodology has a demonstrable impact on the business performance and the value

\section{Tab. 3: Pivot: BSC methodology $\mathbf{x}$ Performance - statistics}

\begin{tabular}{l|c|c|c}
\multicolumn{1}{c|}{ Statistics } & Chi-square & df & p \\
\hline Pearson's chi-square & 12.78406 & $\mathrm{df}=2$ & $\mathrm{p}=.00167$ \\
\hline M-V chi-square & 10.11521 & $\mathrm{df}=2$ & $\mathrm{p}=.00636$ \\
\hline Contingency coefficient & .2689137 & & \\
\hline Cramer's V & .2791981 & & \\
\hline
\end{tabular}

Source: own

\begin{tabular}{|c|c|c|c|c|c|c|c|c|c|}
\hline \multirow[t]{3}{*}{ Tab. 4: } & \multicolumn{9}{|c|}{ Pivot: BSC methodology x Performance - frequency } \\
\hline & \multicolumn{3}{|c|}{ The observed frequency } & \multicolumn{3}{|c|}{ Expected frequency } & \multicolumn{3}{|c|}{$\begin{array}{l}\text { Observed minus the expected } \\
\text { frequencies (residue) }\end{array}$} \\
\hline & $\begin{array}{l}\text { BSC is } \\
\text { not used }\end{array}$ & BSC is used & Total & $\begin{array}{l}\text { BSC is } \\
\text { not used }\end{array}$ & $\begin{array}{l}\text { BSC } \\
\text { is used }\end{array}$ & Total & $\begin{array}{l}\text { BSC is not } \\
\text { used }\end{array}$ & $\begin{array}{l}\text { BSC } \\
\text { is used }\end{array}$ & Total \\
\hline Group 1 & 68 & 4 & 72 & 65.41463 & 6.58537 & 72.0000 & 2.58537 & -2.58537 & 0.0000 \\
\hline Group 2 & 58 & 3 & 61 & 55.42073 & 5.57927 & 61.0000 & 2.57927 & -2.57927 & 0.0000 \\
\hline Group 3 & 23 & 8 & 31 & 28.16463 & 2.83537 & 31.0000 & -5.16463 & 5.16463 & 0.0000 \\
\hline Row total & 149 & 15 & 164 & 149.0000 & 15.0000 & 164.0000 & 0.00 & 0.00 & 0.00 \\
\hline
\end{tabular}

Note: Group 1 (ROE < 0, 0-2\%); Group 2 (ROE 2-4\%, 4-7\%); Group 3 (ROE 7-10\%, over 10\%).

in terms of residues, it is clear that the use of the methodology can be achieved aboveaverage performance (ROE value of $7 \%$ ). If the enterprises do not use the BSC methodology, they will achieve an average or even belowaverage performance (ROE of $7 \%$ or less), which also reflects the hypothesis $\mathrm{H} 1$.

From previous data - Tables 5, 6, we can conclude that the KPI system affects the performance of enterprises, while from the residue data is evident that businesses using $\mathrm{KPI}$ they achieve a better performance with ROE of $4 \%$. It follows that the hypothesis $\mathrm{H} 2$ is also confirmed.
In terms of non-financial indicators we paid attention to especially orientations on the environment and analysis results (Tabs. 7, 8) revealed statistically significant dependence of business performance and the orientation of the environment, and similarly as in the previous case, enterprises typically achieve better business performance with ROE of $4 \%$.

The sample analysis of all relevant sectors (164 enterprises) showed that on the overall performance have impacts except to traditional indicators such as output of financial accounting also other factors. While the use of BSC methodology and KPI was foreseen 


\section{Ekonomika a management}

Tab. 5: Pivot: KPI x Performance - statistics

\begin{tabular}{l|c|c|c}
\multicolumn{1}{c|}{ Statistics } & Chi-square & df & p \\
\hline Pearson's chi-square & 4.844668 & $\mathrm{df}=1$ & $\mathrm{p}=.02773$ \\
\hline The M-V chi-square & 4.588895 & $\mathrm{df}=1$ & $\mathrm{p}=.03218$ \\
\hline Phi coefficient for $2 \times 2$ tables & .1718740 & & \\
\hline The contingency coefficient & .1693902 & & \\
\hline
\end{tabular}

\begin{tabular}{|c|c|c|c|c|c|c|c|c|c|}
\hline & \multicolumn{3}{|c|}{ The observed frequency } & \multicolumn{3}{|c|}{ Expected frequency } & \multicolumn{3}{|c|}{$\begin{array}{l}\text { Observed minus the expected } \\
\text { frequencies (residue) }\end{array}$} \\
\hline & $\begin{array}{c}\mathrm{KPI} \text { is not } \\
\text { used }\end{array}$ & $\begin{array}{c}\text { KPI } \\
\text { is used }\end{array}$ & Total & $\begin{array}{c}\text { KPI } \\
\text { is not used }\end{array}$ & $\begin{array}{c}\text { KPI } \\
\text { is used }\end{array}$ & Total & $\begin{array}{c}\text { KPI } \\
\text { is not used }\end{array}$ & $\begin{array}{c}\text { KPI } \\
\text { is used }\end{array}$ & Total \\
\hline Group 1 & 100 & 7 & 107 & 95.9085 & 11.0915 & 107.0000 & 4.09146 & -4.09146 & 0.0000 \\
\hline Group 2 & 47 & 10 & 57 & 51.09146 & 5.90854 & 57.0000 & 4.09146 & -4.09146 & 0.0000 \\
\hline Row total & 147 & 17 & 164 & 147.0000 & 17.0000 & 164.0000 & 0.00 & 0.00 & 0.00 \\
\hline
\end{tabular}

Note: Group 1 (ROE<0, 0-2\%, 2-4\%); Group 2 (ROE 4-7\%, 7-10\%, over 10\%).

\section{Tab. 7: Pivot: Non-financial indicator Orientation of environment x Performance - statistics}

\begin{tabular}{l|c|c|c}
\multicolumn{1}{c|}{ Statistics } & Chi-square & df & p \\
\hline Pearson's chi-square & 5.073809 & $\mathrm{df}=1$ & $\mathrm{p}=.02429$ \\
\hline The M-V chi-square & 4.815006 & $\mathrm{df}=1$ & $\mathrm{p}=.02821$ \\
\hline Phi coefficient for $2 \times 2$ tables & .1758916 & & \\
\hline The contingency coefficient & .1732323 & & \\
\hline
\end{tabular}

\begin{tabular}{|c|c|c|c|c|c|c|c|c|c|}
\hline \multirow[t]{3}{*}{ Tab. 8: } & \multicolumn{9}{|c|}{$\begin{array}{l}\text { Pivot: Non-financial indicator Orientation of environment } x \text { Performance } \\
\text { - frequency }\end{array}$} \\
\hline & \multicolumn{3}{|c|}{ The observed frequency } & \multicolumn{3}{|c|}{ Expected frequency } & \multicolumn{3}{|c|}{$\begin{array}{l}\text { Observed minus the expected } \\
\text { frequencies (residue) }\end{array}$} \\
\hline & $\begin{array}{l}\text { Do not } \\
\text { focused }\end{array}$ & Focused & Total & $\begin{array}{l}\text { Do not } \\
\text { focused }\end{array}$ & Focused & Total & $\begin{array}{l}\text { Do not } \\
\text { focused }\end{array}$ & Focused & Total \\
\hline Group 1 & 99 & 8 & 107 & 94.637 & 12.3963 & 107.0000 & 4.39634 & -4.39634 & 0.0000 \\
\hline Group 2 & 46 & 11 & 57 & 50.39634 & 6.60366 & 57.0000 & 4.39634 & -4.39634 & 0.0000 \\
\hline Row total & 145 & 19 & 164 & 145.0000 & 19.0000 & 164.0000 & 0.00 & 0.00 & 0.00 \\
\hline
\end{tabular}

Note: Group 1 (ROE<0, 0-2\%, 2-4\%); Group 2 (ROE 4-7\%, 7-10\%, over 10\%). 
higher, this fact is confirmed also in the area of non-financial corporate orientation to the environment. Hypothesis $\mathrm{H} 3$ is also accepted. All of the above findings and conclusions may have great importance on the business practices due to the fact that at present Slovak enterprises use these tools in a relatively lesser extent compared to the research carried out abroad.

As we mentioned in chapter 1.3 in connection with information systems is clear that effective SPMS should be supported by application of knowledge $\mathrm{BI}$ information system in a stronger extent. It seems that it is just the set of information tools from ERP to knowledge information systems like $\mathrm{BI}$, which gives to methods and tools included in the SPMS a particular "spirit" and encouraging them dynamically towards achieving a higher economic performance of the company. From this our research is evident that the key tool in increasing the overall business performance of the enterprise in the selected Slovak industries seems to be employing a system of strategic performance management of the company, supported by a knowledge-based BI Information System (enterprises using BI system achieve better performance with ROE over 4\%) (Rajnoha et al., 2016).

\subsection{Estimation of Corporate Sustainability through Composite Index and its Impact on Business Performance}

Within the qualitative research, as we declared in the Methodology section we at first collected the necessary data for indexes to be created in each sustainability area and then summarize in a composite index of sustainable development. The results of the sub-index and also the composite index $\left(I_{C S D}\right)$ are shown in Tab. 9.

Tab. 9: $\begin{aligned} & \text { Results of individual sub-indexes and the composite index of sustainable } \\
& \text { development }\end{aligned}$
\begin{tabular}{l|l|c|c|c|c|c|c} 
Shortcut & \multicolumn{1}{|c}{ Title } & $\mathbf{2 0 0 9}$ & $\mathbf{2 0 1 0}$ & $\mathbf{2 0 1 1}$ & $\mathbf{2 0 1 2}$ & $\mathbf{2 0 1 3}$ & $\mathbf{2 0 1 4}$ \\
\hline Is,1 & Economic sub-index & 0.345 & 0.545 & 0.510 & 0.430 & 0.751 & 0.592 \\
\hline Is,2 & Social sub-index & 0.244 & 0.151 & 0.689 & 0.746 & 0.619 & 0.527 \\
\hline Is,3 & Environmental sub-index & 0.681 & 0.241 & 0.181 & 0.331 & 0.459 & 0.186 \\
\hline$I_{\text {CSD }}$ & Composite index of SD & 0.424 & 0.312 & 0.460 & 0.503 & 0.610 & 0.435 \\
\hline
\end{tabular}

Tab. 10: Testing correlation through Spearman correlation coefficient

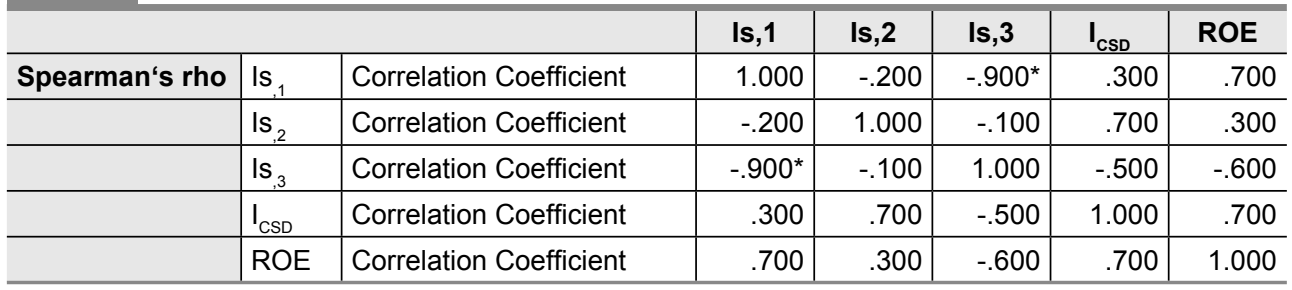

Tab. 9 shows that the composite index of sustainable development ranges from 0.31 (2010) to a value of 0.435 (2014). These values can be considered as an average. In principle: the higher value of the composite index, the higher is also improvement of the enterprise towards sustainability. The same we can say about the evaluation of sub-indexes. In 2009 and 2010 were the lowest reported values, while drop was mainly due to the significant decrease of the environmental and moderate decrease of social sub-index. The total average value of the composite index is 0.46 , which means that in the enterprise are substantial reserves 


\section{Fig. 2: Relationship between $\mathrm{I}_{\mathrm{CSD}}$ and indicator ROE}

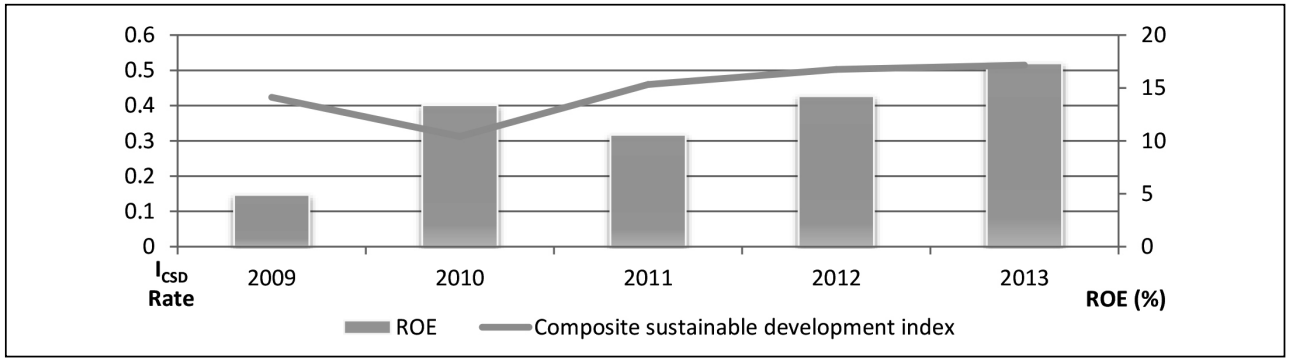

Source: own

for the improvement, whereby the individual sub-indices (Is, 1 ; Is, 2 ; Is, 3 ) should point out the potential hazards that cause this status.

Our aim was also to find out whether there is a relationship between the composite index of sustainable development and individual sub-indices and indicator of ROE. For this purpose we used Spearman's rank correlation coefficient (Tab. 10). Direct moderate correlation is apparent between economic sub-index and also composite index of sustainable development and indicator of ROE. The connection of environmental and social subindex separately to ROE had not been shown sufficiently.

For the once, we assume that the measures it has taken place in the context of sustainable development (which are captured in various sustainability indices) may have a delayed effect, respectively there is a time lag between the adoption of certain measures and economic (financial) consequences. We have analyzed the delay for a one year. This assumption is supported by the following chart and from which it can be clearly seen late changes in ROE indicator in connection to the development of a composite index of sustainability (Fig. 2). In this case it exists the observed strong, respectively moderately strong direct link between $\mathrm{I}_{\mathrm{CSD}}$ and indicator ROE.

\section{Discussion, Limitations and Conclusion}

Performance measurement system has undergone for several phases into its present form. At the beginning the system was focused solely on financial indicators based on accounting data from the past previous years. Whereas the businesses do not operate in a closed system of relations, but rather in a dynamically evolving environment, it was necessary to look at the business performance in other way and take account of its nature. The attention has given to the non-financial indicators and more complex systems to support business performance, with an emphasis on strategy and business objectives (in terms of technological innovations, the environment, social aspects, IT).

With a growing awareness of natural limits and social issues it comes to the fore the corporate sustainability concept and its measurement. In this area are still some limitations, especially in the linking of economic, environmental and social performance. We can conclude that SPMS and corporate sustainability measurement system are in the some relation. More and more businesses are willing to invest time and energy on building SPMS focused on non-financial objectives and indicators, as well as sustainable development of enterprises. These endeavors, however, definitely not be inconsistent with the achievement of the overall economic performance of the company measured by ROE, which confirmed the partial results of our empirical research. The development of individual periods of performance measurement system we further characterize in the following Fig. 3. Apart from the brief description of these periods it is mention also the connection with the specific results of our research. We identified and analyzed parameters for measuring and managing corporate performance, whereby a key finding was the size of ROE. We examined selected tools and concepts from the perspective of the different phases of performance measurement 
Fig. 3: The overview of particular phases of performance measurement systems with our research findings

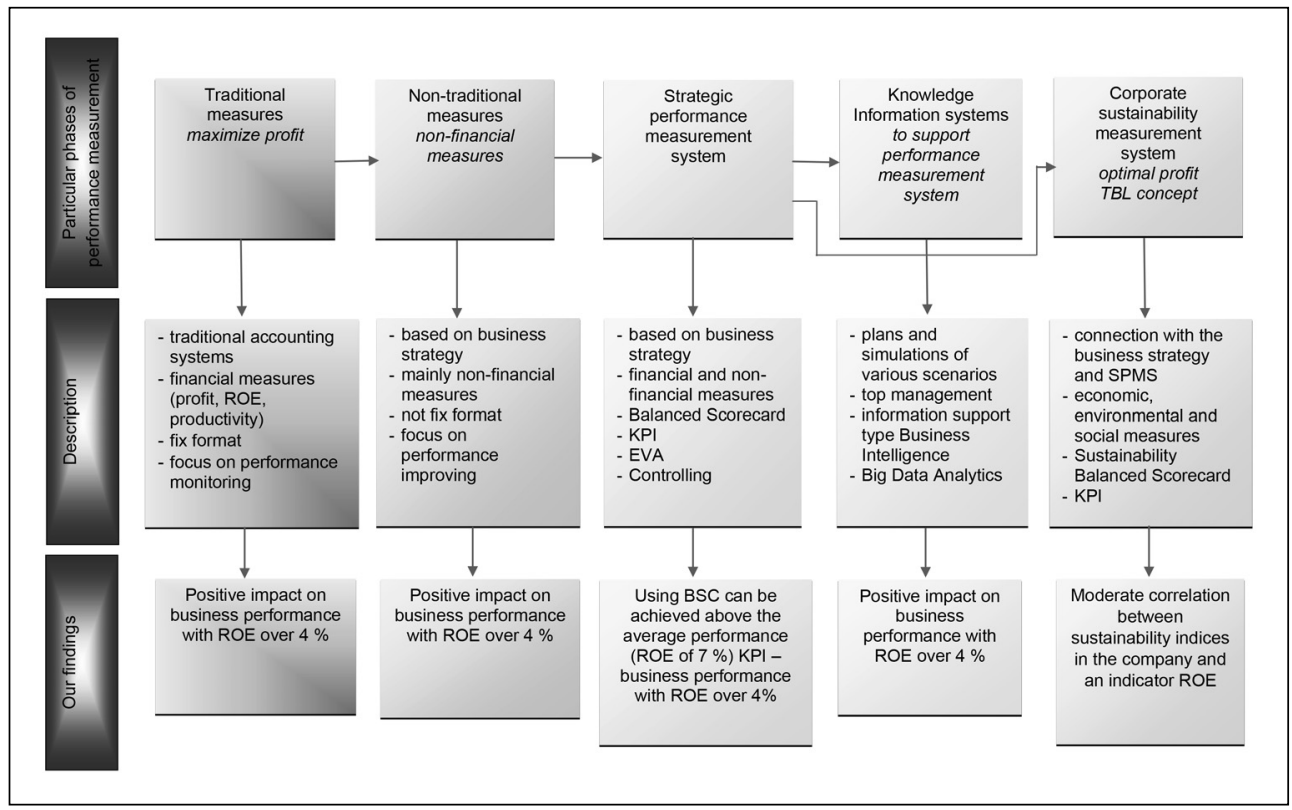

Source: own

systems stated in Part 1. Firstly, we analyzed the influence of BSC methodology to the business performance. In conclusion BSC methodology has a demonstrable impact on the business performance which means that through its use can be achieved an above-average performance (ROE value of $7 \%$ ). Secondly, also KPI system affects the performance of enterprises; businesses using $\mathrm{KPI}$ achieved a better performance with ROE of $4 \%$. Thirdly, in terms of non-financial indicators especially orientation on the environment the analyses demonstrated statistically significant dependence between examined parameters (better business performance with ROE of $4 \%$ ). Fourthly, in the case that companies do not have the knowledge information system as a complex system and do not take into account its implementation they tended to have a lower level of performance. This means that the $\mathrm{BI}$ knowledge information system has a major impact on business performance.

Further, we supported the fact that direct moderate correlation is apparent between economic sub-index and also composite index of sustainable development and indicator of ROE. The connection of environmental and social sub-index separately to ROE had not been shown sufficiently. The assumption of a delayed effect was shown in sustainability indices. In this case it exists the observed strong, respectively moderately strong direct link between sustainability indices and indicator ROE. In the sustainable development issue, we can say that the environmental sub-index has the effect of reducing the total value of composite index; on the contrary the social subindex maintained this value. Due to the changes that occur in environmental (existential), we think that the linking between sustainable development and business performance is the way according the motto "save the planet and keep your performance". However, we can conclude that the index of sustainable development is a challenge for enterprises reflecting a growing need for change purely short-term oriented, consumerist patterns of production and consumption.

Finally, we conclude that SPMS in its current form has gone through a certain phases 
of development which are characterized by particular features. We presented the brief view of these phases with support of our research results. Between SPMS and corporate sustainability we see the certain connection (a complex support of decision making, improving performance, mainly intended for larger companies, ability to manage the business in a predetermined direction of the longer term, respecting the change in global thinking with regard to sustainable development).

Our research has been processed with the following limitations:

- Sample size. Due to the lower return it was not possible to reach a larger number of enterprises, so research sample was 164 enterprises.

- ROE indicator. This limitation would be to use only one parameter to measure performance in the form of ROE. The most appropriate indicator should be indicator EVA, but because of the problems of availability of data, we focused on the ROE indicator. In further research would be applicable to extend the parameter of another (ROA, ROI, NOPAT).

- Examination of corporate sustainability in the questionnaire survey. We examined the corporate sustainability concept in the example of a particular enterprise. Thereby it is absent a preview to the concept and processing a large number of enterprises.

- Performance of the enterprise surveyed. Despite the fact that the results revealed moderate interdependence between sustainability indices and indicator ROE, it is questionable to what extent the particular index contributes to business performance.

This paper is the partial result of the Ministry of Education of Slovak Republic grant project VEGA Nr. 1/0537/16 - Methods and models of Strategic Business Performance Management and their comparison in companies and multinational corporations.

\section{References}

Afonina, A. (2015). Strategic Management Tools and Techniques and Organizational Performance: Findings from the Czech Republic. Journal of Competitiveness, 7(3), 1936. doi:10.7441/joc.2015.03.02.

Ayvazyan, S., \& Afanasyev, M. (2016). The Size of Innovation Space as a Factor of
Innovation Activity in Regions. Montenegerin Journal of Economics, 12(2), 7-27. doi:10.14254/1800-5845.2016/12-2/11.

Ahmed, P. K., Lim, K. K., \& Zairi, M. (1999). Measurement practice for knowledge management. Journal of Workplace Learning: Employee Counselling Today, 11(8), 304-311. doi:10.1108/13665629910300478.

Baron, D. P., Harjoto, M. A., \& Jo, H. (2012). The Economics and Politics of Corporate Social Performance. Business and Politics, 13(2), 1-48.

Belás, J., \& Gabčová, L. (2016). The Relationship among Customer Satisfaction, Loyalty and Financial Performance of Commercial Banks. E\&M Ekonomie a Management, 19(1), 132-147. doi:10.15240/ tul/001/2016-1-010.

Belás, J., Vojtovič, S., \& Ključnikov, A. (2016). Microenterprises and Significant Risk Factors in Loan Process. Economics and Sociology, 9(1), 43-59. doi:10.14254/2071789X.2016/9-1/3.

Bento, A., Bento, R., \& White, L. F. (2014). Strategic Performance Management Systems: Impact on business results. Journal of Computer Information Systems, 54(3), 25-33. doi:10.1080 /08874417.2014.11645701.

Bisbe, J., \& Malagueño, R. (2012). Using strategic performance measurement systems for strategy formulation: Does it work in dynamic environments? Management Accounting Research, 23(4), 296-311. doi:10.1016/j. mar.2012.05.002.

Braam, G., \& Nijssen, E. (2004). Performance effects of using the BSC: a note on the Dutch experience. Long Range Planning, 37(4), 335-349. doi:10.1016/j.Irp.2004.04.007.

Burgess, T. F., Ong, T. S., \& Shaw, N. E. (2007). Traditional or contemporary? The prevalenceofperformancemeasurementsystem types. International Journal of Productivity and Performance Management, 56(7), 583-602. doi:10.1108/17410400710823633.

Cochran, P. L., \& Wood, R. A. (1984). Corporate Social Responsibility and Financial Performance. Academy of Management Journal, 27(1), 42-56.

Dossi, A., \& Pateli, L. (2010). You Learn From What You Measure: Financial and Nonfinancial Performance Measures. Long Range Planning, 43(4), 498-526. doi:10.1016/j. Irp.2010.01.002.

Eccles, R. G., Perkins, K. M., \& Serafeim, G. (2012). How to Become a Sustainable Company. 
MIT Sloan Management Review. 53(4), 43-50.

Elbashir, M., Collier, P., \& Davern, M. (2008). Measuring the effects of business intelligence systems: The relationship between business process and organizational performance. International Journal of Accounting Information Systems, 9(3),135-153. doi:10.1016/j.accinf.2008.03.001.

Fauzi, H., Svensson, G., \& Rahman, A. A. (2010). Triple Bottom Line as Sustainable Corporate Performance: A proposition for the Future. Journal of Sustainability, 2(5), 1345-1360.

Figge, F., Hahn, T., Schaltegger, S., \& Wagner, M. (2002). The Sustainability Balanced Scorecard - Linking sustainability management to business strategy. Business Strategy and the Environment, 11(5), 269-284. doi:10.1002/bse.339.

Garcia Castro, R., Ariño, M. A., \& Canela, M. A. (2010). Does Social Performance Really Lead to Financial Performance? Accounting for Endogeneity. Journal of Business Ethics, 92(1), 107-126. doi:10.1007/s10551-009-0143-8.

Gavurová, B. (2011). Systém Balanced Scorecard v podnikovom riadení. Ekonomický časopis, 59(2), 163-177.

Gimbert, X., Bisbe, J., \& Mendoza, X. (2010). The Role of Performance Measurement Systems in Strategy Formulation Processes. Long Range Planning, 43(4), 477-497. doi:10.1016/j.Irp.2010.01.001.

Gunasekaran, A., \& Kobu, B. (2007). Performance measures and metrics in logistics and supply chain management: a review of recent literature (1995-2004) for research and applications. International Journal of Production Research, 45(12), 2819-2840. doi:10.1080/00207540600806513.

Hawn, O., \& Ioannou, I., (2012). Do actions speak louder than words? The case of corporate social responsibility (CSR). Academy of Management Annual Meeting Proceedings, 1(1). doi:10.5465/AMBPP.2012.329.

Chenhall, R. H. (2005). Integrative strategic performance measurement systems, strategic alignment of manufacturing, learning and strategic outcomes: an exploratory study. Accounting, Organizations and Society, 30(5), 395-422. doi:10.1016/j.aos.2004.08.001.

Chenhall, R. H., \& Langfield-Smith, K. (2007). Multiple Perspectives of Performance Measures. European Management Journal, 25(4), 266-282. doi:10.1016/j.emj.2007.06.001.

Işik, Ö., Jones, M. C., \& Sidorova, A. (2013).
Business intelligence success: The roles of BI capabilities and decision environments. Information and Management, 50(1), 13-23. doi:10.1016/j.im.2012.12.001.

Ittner, C. D., \& Larcker, D. F. (1998). Innovations in performance measurement: Trends and research implications. Journal of Management Accounting Research, 10, 205-238.

Ittner, C. D., Larcker, D. F., \& Randall, T. (2003). Performance implications of strategic performance measurement in financial services firms. Accounting, Organizations and Society, 28(7-8), 715-741. doi:10.2139/ssrn.395824.

Jurigová, Z., \& Lencsésová, Z. (2015). Monitoring System of Sustainable Development in Cultural and Mountain Tourism Destinations. Journal of Competitiveness, 7(1), 35-52. doi:10.7441/joc.2015.01.03.

Kaplan, R. S., \& Norton, D. P. (2005). The Balanced Scorecard: Measures That Drive Performance. Harvard Business Review, 83(7), 172-180.

Kennerley, M., \& Neely, A. (2002). A framework of the factors affecting the evolution of performance measurement systems. International Journal of Operations \& Production Management, 22(11), 1222-1245. doi:10.1108/01443570210450293.

Keeble, J. J., Topiol, S., \& Berkeley, S. (2003). Using Indicators to Measure Sustainability Performance at a Corporate and Project Level. Journal of Business Ethics, 44(2), 149-158. doi:10.1023/A:1023343614973.

Knápková, A., Homolka, L., \& Pavelková, D. (2014). Utilization of Balanced Scorecard and the effect of its use on the Financial Performance of Companies in the Czech Republic. E\&M Ekonomie a Management, 17(2), 146-160. doi:10.15240/tul/001/2014-2-011.

Koh, P. S., Qian, C., \& Wang, H. (2014). Firm Litigation Risk and the Insurance Value of Corporate Social Performance. Strategic Management Journal, 35(10), 1464-1482. doi:10.1002/smj.2171.

Korauš, A., Štefko, R., \& Dobrovič, J. (2015). Acqusition Activity in Financial Sector. In European Financial Systems 2015: Proceedings of the 12th International Scientific Conference (pp. 277-286).

Kozubíková, L., Belás, J., Ključnikov, A., \& Virgelrová, Z. (2015). Differences in approach to selected constructs of entrepreneurial orientation in SME segment regarding the selected socio-demographic factors. Transformations in 
Business \& Economics, 14(3C), 333-355.

Krajnc, D., \& Glavič, P. (2005). A model for integrated assessment of sustainable development. Resources, Conservation \& Recycling, 43(2), 189-208. doi:10.1016/j. resconrec.2004.06.002.

Lajčin, D., Frankovský, M., \& Štefko, R. (2012). Possibilities of Predicting the Behavior of Managers When Coping with Demanding Situations in Managerial Work. Ekonomický časopis, 60(8), 835-853.

Lo, S. F., \& Sheu, H. J. (2007). Is Corporate Sustainability a Value-Increasing Strategy for Business? Corporate Governance: An International Review, 15(2), 345-358. doi:10.1111/j.1467-8683.2007.00565.x.

López, M. V., Garcia, A., \& Rodriquez, L. (2007). Sustainable Development and Corporate Performance: A Study Based on the Dow Jones Sustainability Index. Journal of Business Ethics, 75(3), 285-300. doi:10.1007/ s10551-006-9253-8.

Maletic, M., Maletic, D., Dahlgaard, J., Dahlgaard, S. M., \& Gomiscek, B. (2015). Do corporate sustainability practices enhance organizational economic performance? International Journal of Quality and Service Sciences, 7(2/3), 184-200. doi:10.1108/ IJQSS-02-2015-0025.

Marková, V. (2012). Podnikanie z aspektu konceptu spoločenskej zodpovednosti podniku. In Management of Organizations in Real and Virtual Environment: Opportunities and Challenges IV. Proceedings of scientific papers. Banská Bystrica: Ekonomická fakulta Univerzity Mateja Bela v Banskej Bystrici.

Melchert, F., Winter, R., \& Klesse, M. (2004). Aligning Process Automation and Business Intelligence to Support Corporate Performance Management. In AMCIS 2004 Proceedings. Retrieved May 15, 2016, from http://aisel. aisnet.org/amcis2004/507.

Morgan, R. E., \& Strong, C. A. (2003). Business performance and dimensions of strategic orientation. Journal of Business Research, 56(3), 163-176. doi:10.1016/S01482963(01)00218-1.

Neely, A., Mills, J., Platts, K., Richards, H., Gregory, M., Bourne, M., \& Kennerley, M. (2000). Performance measurement system design: developing and testing a process-based approach. International Journal of Operations \& Production Management, 20(10), 1119-1145. doi:10.1108/01443570010343708.
Novák, P., \& Popesko, B. (2014). Cost Variability and Cost Behaviour in Manufacturing Enterprises. Economics and Sociology, 7(4), 89-103. doi:10.14254/2071-789X.2014/7-4/6.

Nudurupati, S. S., \& Bititci, U. S. (2005). Implementation and impact of IT-supported performance measurement systems. Production Planning \& Control: The Management of Operations, 16(2), 152-162. doi:10.1080/0953 7280512331333057.

Pava, M. L., \& Krausz, J. (1996). The Association between Corporate SocialResponsibility and Financial Performance: The Paradox of Social Cost. Journal of Business Ethics, 15(3), 321-357. doi:10.1007/ BF00382958.

Petrini, M., \& Pozzebon, M. (2009). Managing sustainability with the support of business intelligence: Integrating socioenvironmental indicators and organizational context. Journal of Strategic Information Systems, 18(4), 178-191. doi:10.1016/j. jsis.2009.06.001.

Perkins, M., Grey, A., \& Remmers, H. (2014). What do we really mean by „Balanced Scorecard"? International Journal of Productivity and Performance Management, 63(2), 148169. doi:10.1108/IJPPM-11-2012-0127.

Ranjan, J. (2009). Business Intelligence: Concepts, Components, Techniques and Benefits. Journal of Theoretical and Applied Information Technology, 9(1), 60-70.

Rajnoha, R., Štefko, R., Merková, M., \& Dobrovič, J. (2016). Business Intelligence as a Key Information and Knowledge Tool for Strategic Business Performance. E\&M Ekonomie a Management, 19(1), 183-203. doi:10.15240/tul/001/2016-1-013.

Rigby, D., \& Bilodeau, B. (2015). Management Tools and Trends 2015. Boston: Bain \& Company. Retrieved April 4, 2016, from http://www.bain.com/publications/articles/ management-tools-and-trends-2015.aspx.

Romolini, A., Gori, E., \& Fissi, S. (2015). Public Corporate Governance and Performance Information in Local Utilities: The Different Perceptions of Politicians and Managers. Administration and Public Management Journal, (25), 55-77.

Rudd, J., Greenley, G., Beatson, A., \& Lings, I. (2008). Strategic planning and performance: Extending the debate. Journal of Business Research, 61(2), 99-108. doi:10.1016/j. jbusres.2007.06.014. 
Saaty, T. L. (2008). Analytical Hierarchy Process: Planning, Priority Setting, Resource Allocation. International Journal of Services Sciences, 1(1), 83-98. doi:10.1504/ IJSSCI.2008.017590.

Searcy, C. (2012). Corporate Sustainability Performance Measurement Systems: A Review and Research Agenda. Journal of Business Ethics, 107(3), 239-253. doi:10.1007/s10551011-1038-z.

Servaes, H., \& Tamayo, A. (2013). The Impact of Corporate Social Responsibility on Firm Value: The role of Customer Awareness. Management Science, 59(5), 1045-1061. doi:10.1287/mnsc.1120.1630.

Sharma, A. K., \& Kumar, S. (2010). Economic Value Added (EVA) - Literature Review and Relevant Issues. International Journal of Economics and Finance, 2(2), 200220. doi:10.5539/ijef.v2n2p200.

Schaltegger, S., Lüdeke-Freund, F., \& Hansen, E. G. (2012). Business cases for sustainability: the role of business model innovation for corporate sustainability. International Journal of Innovation and Sustainable Development, 6(2), 95-119. doi:10.1504/IJISD.2012.046944.

Streimikiene, D. (2014). Comparative Assessment of Environmental Indicators of Quality of Life in Romania and Lithuania. Economics \& Sociology, 7(1), 11-21. doi:10.14254/2071-789X.2014/7-1/2.

Šoltés, V., \& Gavurová, B. (2015). Modification of performance measurement system in the intentions of globalization trends. Polish Journal of Management Studies, 11(2), 160-170.

Tangen, S. (2004). Performance measurement: from philosophy to practice. International Journal of Productivity and Performance Management, 53(8), 726-737. doi:10.1108/17410400410569134.

Tuček, D., Hájková, M., \& Tučková, Z. (2013). Utilization level of Business management in Czech enterprises - objectives and factors. E\&M Ekonomie a Management, 16(2), 81-98.

Van der Stede, W. A., Chow, Ch. W., \& Lin, T. W. (2006). Strategy, Choice of Performance Measures, and Performance. Behavioral Research in Accounting, 18(1), 185-205. doi:10.2308/bria.2006.18.1.185.

Virglerová, Z., Dobeš, K., \& Vojtovič, S. (2016). The Perception of the State's Influence on its Business Environment in the SMEs from Czech Republic. Administration and Public Management Journal, (26), 78-96.

Waddock, S. A., \& Graves, S. B. (1997). The Corporate Social Performance-Financial Performance Link. Strategic Management Journal, 18(4), 303-319. doi:10.1002/ (SICI)1097-0266(199704)18:4<303::AIDSMJ869>3.0.CO;2-G.

Yeniyrt, S. (2003). A literature review and integrative performance measurement framework for multinational companies. Marketing Intelligence \& Planning, 23(3), 134142. doi:10.1108/02634500310474957.

doc. Ing. Rastislav Rajnoha, PhD. Tomas Bata University in Zlín

Faculty of Management and Economics

Department of Industrial Engineering and Information Systems rajnoha@fame.utb.cz

Ing. Petra Lesníková, PhD.

Technical University in Zvolen

Faculty of Wood Sciences and Technology Department of Business Economics lesnikova@tuzvo.sk

doc. RNDr. Vladimír Krajčík, Ph.D. Pan-European University Faculty of Informatics vladimir.krajcik@paneurouni.com 


\title{
Abstract
}

\section{INFLUENCE OF BUSINESS PERFORMANCE MEASUREMENT SYSTEMS AND CORPORATE SUSTAINABILITY CONCEPT TO OVERAL BUSINESS PERFORMANCE: "SAVE THE PLANET AND KEEP YOUR PERFORMANCE"}

\author{
Rastislav Rajnoha, Petra Lesníková, Vladimír Krajčík
}

Nowadays the dissatisfaction with only financial indicators has led to a focus on non-traditional areas of performance measurement as Balanced Scorecard, environment indicators and others. Moreover many recent studies has focused on the corporate sustainability concept and performance measurement interconnection. The aim of this paper is to identify the relationship between selected management tools and concepts of various development phases of strategic performance measurement systems to overall business performance measured by indicator ROE. Similarly the aim is to identify the relationship between the sustainability index and indicator ROE as a key aspect in terms of the current climate crisis. Our most important findings bring new information and knowledge for the strategic transformation from traditional business performance measurement system to strategic and sustainable performance measurement system. Specifically we found out that the BSC methodology has a demonstrable impact on the business performance. Also KPI system and orientation on the environment affect the performance of enterprises. In the case that companies do not have the knowledge information system as a complex system and do not take into account its implementation they tended to have a lower level of performance. This means that the BI knowledge information system has a major impact on business performance. Regarding to the corporate sustainability concept we can confirm that the direct moderate correlation is apparent between economic sub-index and also composite index of sustainable development and indicator of ROE. The connection of environmental and social sub-index separately to ROE had not been shown sufficiently. Based on results we can conclude that the index of sustainable development is a challenge for enterprises reflecting a growing need for change purely short-term oriented, consumerist patterns of production and consumption.

Key Words: Business performance, financial measures, non-financial measures, strategic performance measurement system, knowledge information system, sustainability measurement system.

JEL Classification: M21, M14.

DOI: 10.15240/tul/001/2017-1-008 